\title{
Regulation of "Religion" and the "Religious": The Politics of Judicialization and Bureaucratization in India and Indonesia
}

\author{
YÜKSEL SEZGIN \\ Syracuse University
}

MIRJAM KÜNKLER

Princeton University

INTRODUCTION

Resham Bibi, a Muslim wife, declared that she renounced Islam, and thereby asked the district court in Lahore to dissolve her marriage on grounds of apostasy. To verify Resham's claim, the district attorney ordered a plate of pork to the courtroom and asked her to take a bite. When she refused, the judge concluded that her renunciation of Islam was insincere, and thus rejected her request for divorce. This was in 1937. Fifty-one years later, in the case of a Hindu couple who allegedly converted to Islam and contracted a marriage under Muslim family law, justices of the High Court of Andhra Pradesh concluded that the couple's conversion was invalid because the husband did not attend the mosque on Fridays, and the wife continued wearing jewelry, which the court viewed as proof attesting to the couple's continued adherence to Hindu customs (B. Chandra Manikyamma v. B. Sudarsana Rao Alias Saleem Mohammed 1988). In Indonesia, a local Civil Records Office refused in 1995 to register the marriage of Budi Wijaya and Lany Guito, two Indonesians of Chinese descent who married according to Confucian rites, on grounds that Confucianism was not an agama, a religion recognized by the Ministry of

Acknowledgments: Several friends and colleagues have provided valuable feedback at various stages of writing this manuscript, among them the participants of a SSRC-funded workshop, Religious Norms in the Public Sphere, held at the European University Institute, Florence, 16-18 December 2010, as well as the participants of the 2010-2011 Harvard Divinity School WSRP Research Colloquium. We thank them, and the anonymous CSSH reviewers for their very helpful comments. 
Religious Affairs (MORA). According to a 1952 regulation issued by the MORA, the Indonesian government defined agama as an internationally recognized monotheistic creed with a holy scripture, a concept of prophethood, and universal ethical teachings. Belief systems that did not meet these criteria were denied government recognition and their adherents were compelled to register as members of another religion. As a result, the registrar asked Wijaya and Guito to register with a recognized agama, and to remarry according to its rites in order to have their marriage registered.

Both India and Indonesia are multi-religious and pluri-legal states. Both countries have an 80-87 percent religious majority, in India Hindu, in Indonesia Muslim, that is internally highly heterogeneous and bound together more by the overall label than agreement in matters of faith and notions of religious law. Both countries also have sizable minorities. India's are 18 percent of the population, consisting of Muslims (13 percent), Christians (2.3), and Sikhs (1.9). Indonesia's population is 12 percent minority, made up of Christians (10), Hindus (1.7), Buddhists (0.07), and Confucians (0.05). These minorities are also internally highly heterogeneous. ${ }^{1}$ India and Indonesia have developed divergent ways of dealing with this great diversity in their legal and political systems. In India, religious family laws of Hindus, Muslims, Christians, and Parsis are incorporated into an otherwise secular legal system and directly applied by secularly trained justices in civil courts. In Indonesia, by contrast, the legal system is bifurcated: for family matters, Muslims are subject to jurisdiction of Islamic courts where religious judges apply (partially codified) Islamic law, while nonMuslims are subject to secular law applied by the civil courts.

In the following, we identify the two post-independent states' different strategies of managing this diversity, and the consequences these strategies have had in each society on identity politics, which we define as political discourse and activity that emphasize ethnicity- and religion-based inter-group differences. We limit our analysis to the period of 1947-2010 for India, and 1945-1998 for Indonesia, since Indonesia's politics changed radically with the country's democratization in 1998 (whereas India experienced regime continuity after 1947). We argue that the dominant strategy of managing religion in India has been one of judicialization, ${ }^{2}$ while in Indonesia it has been one of bureaucratization. Whereas judicialization, a recurrent phenomenon in democracies, is believed to devitalize normative conflicts, bureaucratization, more frequently associated with authoritarian politics, is often thought of as "locking" these

\footnotetext{
${ }^{1}$ See the Indian Census of 2001 (http://www.censusindia.gov.in/Census_Data_2001/India at glance/religion.aspx); and the Indonesian Census of 2010 (http://sp2010.bps.go.i.j/index.php/site/ tabel?tid=321\&wid=0) (both sites accessed Aug. 2012).

${ }^{2}$ Other institutions and political actors were also involved in the construction and reinvention of Indian religious traditions. However, in this paper we focus on the role of the Indian judiciary, which emerged particularly after the 1950 s as the main fiduciary for the regulation of "religion" and the "religious."
} 
conflicts “in” (Ginsburg and Moustafa 2008; Handberg 1999; Hirschl 2004; Tate 1993). However, contrary to this expectation, we show that because the democratic Indian government was more restrained in its ability to monitor and ensure the compliance by the Indian courts - its fiduciary - with its own political preferences, the consequences of India's policy toward religion have strayed far from the original intention. In Indonesia, by contrast, where government more effectively addressed unintended effects and inefficiencies caused by principal-agent problems, the bureaucratization of the policy toward religion ensured the latter's coherence with the larger nation-building project.

STRATEGIES OF ADDRESSING RELIGIOUS QUESTIONS: JUDICIALIZA -

TION VERSUS BUREAUCRATIZATION

Since both states feature personal law based on religion, their political elites have encountered similar challenges in engaging and regulating religious heterogeneity. They have often confronted the tasks of defining what should count as a religion (e.g., Is Confucianism a religion?), deciding who belongs to which religious community (When is a Muslim a Muslim? When is a Hindu a Hindu?), and determining the role religious identity should play in defining the terms of membership in the political community. However, as the examples above show, India and Indonesia have responded to these challenges in different ways. In Indonesia it was often the bureaucrats of the MORA who entertained questions of religious identity or theological disputes regarding what a "proper" religion should be, while in India it was the (secular) judiciary.

In both cases, there was great continuity in how colonial and postindependence governments engaged religious questions. The British rulers in India recognized personal laws based on religion and empowered Anglo-Indian judges to rule over theological, dogmatic disputes, and questions of religious identity (Derrett 1999: 294-95; Smith 1963: 83-84; Williams 2006: 9). For both political and institutional reasons, which we explore below, India's postcolonial leaders acted similarly, and largely delegated the resolution of divisive religious questions to the courts, thereby contributing to the judicialization of religion. As Dhavan and Nariman (2000) argue, this has resulted in judges virtually assuming the role of "theological authorities" who, by delving into religious texts and practices, determine which tenets of a faith are essential, which aspects are in need of reform, and who may count as a believer-decisions most democracies leave to religious authorities and communities.

As Tate (1993), Hirschl (2004), Handberg (1999), and Ginsburg and Moustafa (2008) demonstrate, politicians usually find great benefit in delegating politically costly issues to judicial institutions. Judicialization can contribute to the effectiveness of legislative and executive policy-making by delegating to the judiciary issues that would hamstring majoritarian institutions (Tate 1995: 33). It also allows shifting blame for unpopular decisions or policy failures to the judiciary, which is more immune from popular pressure than the 
other branches of power. Moreover, judicialization can facilitate a relatively peaceful resolution of potentially divisive issues in a piecemeal fashion by giving disputants a chance to voice their grievances in a public forum (Eisgruber and Sager 2007; Scheingold 2004). In this respect, as some have suggested, devolution of religious questions to the judiciary can help maintain peaceful relations among different communities and allow the state to advance its sociopolitical agenda (Hirschl 2008: 1200-6). We examine this assumption below in the case of India. Contrary to expectations, we conclude that judicialization has exacerbated identity politics and deepened ethno-religious schisms.

The independent Indonesian state, on the other hand, opted for bureaucratization of religion; that is, it allocated authority to a specialized agency to delineate what constitutes "religion" or "the religious." In this it continued both Dutch and Japanese colonial policies. While Sukarno (1945-1965) went from overt courtship to overt suppression of religious actors within a period of fifteen years, the policy throughout the Suharto era (1966-1998) closely resembled the Dutch colonial regime's so-called "Ethical Policy" (Benda 1958): tolerating and at times even strengthening religion in society and allowing the large Islamic organizations to carry out much of the social-service provision, while keeping political Islam at bay. Institutionally, what became the post-independence institutional framework of religion-state relations was built on that of the Japanese administration. The Office of Religious Affairs, incepted by the Japanese during the 1942-1945 occupation, evolved into the MORA after independence. In fact, independent Indonesia's policy of requiring governmental recognition of religion, and the consequent molding of religion into ministry-defined categories, followed the Japanese approach. Like State Shintoism in Japan, pancasila in Indonesia was elevated to a pan-religious national ethos (Hardacre 1989).

Although governments that are engaged in bureaucratizing religion tend to depict it as a process that is largely "technical," it is often ridden with conflict and exclusion, as alternative sources of meaning and beliefs are systematically suppressed by agencies imposing statist notions of religion. In this respect, one could expect the bureaucratization of religion, particularly in a multi-religious society like Indonesia, to further escalate identity politics that would fuel ethno-religious differences among its citizens. However, Indonesia has been relatively successful in promoting a (pancasila-based) civic national identity among its citizens. While religious violence perpetrated by orthodox Muslims against minority Muslim groups (Ahmadiyya, Shiites) is a real threat to religious harmony today, tensions between Muslims and other religious groups (Christians, Hindus, and Buddhists) have subsided in the past ten years (Jones 2013).

In the final part of the paper, we argue that the surprising outcomes across the two societies can be explained with reference to the relationship between the principal (the government) and the agent/fiduciary (the Indonesian MORA and the Indian judiciary, respectively). The autonomy of India's 
independent judiciary allowed it to become increasingly activist in religious questions and for its rulings to diverge considerably from the Congress governments' policy preferences (especially those of early Congress leaders). In Indonesia, by contrast, the agent to whom religious policy was delegated, the MORA, closely implemented the government's directives across the archipelago, and folded the policy toward religion into the larger nation-building project.

Beyond the literatures on judicialization, bureaucratization, and political delegation (Thatcher and Sweet 2003; Sweet 2003; Tallberg 2003), we will also speak to the nascent body of comparative work on state-religion relations (Casanova 2006; Fox 2006). The great variation with which religious laws are applied in formally secular countries is still underappreciated in the field, and only in recent years have scholars begun to study religion-state relations outside the West more comparatively. The comparison we employ here suggests that scholars will do well to focus on four questions when studying the application of religious law in secular states: Who makes the law? How rigidly is it defined? Who applies the law? And what ends does it serve (managing diversity, accommodating communal demands, deactivating political rivalries)? As countries of the Middle East and North Africa embark on new constitutional projects in which the relationship between religion and state is being redefined, few issues could be more important to understand than the medium- and longterm consequences of the policy toward religion, of the choice of agent or fiduciary responsible for the implementation of that policy, and of the extent to which the implementation is subject to democratic oversight.

JUDICIALIZATION: THE SECULAR INDIAN STATE'S RESPONSE TO

QUESTIONS OF RELIGION AND RELIGIOUS IDENTITY

British India was deeply divided along communal, linguistic, and caste lines. These communal divisions reached their climax in 1947 when the country partitioned into two independent states: Pakistan for Muslims and India for everyone else. Although early Congress leaders (Gandhi, Nehru, Patel, Prasad) differed regarding how the new state should relate to religion, and particularly Hinduism, they were predominantly of the opinion that independent India, unlike Pakistan, should be a non-communal, secular, and democratic nation in which all citizens would be treated equally regardless of their ethno-religious identities. For instance, in 1950 Sardar Patel, India's first home minister and deputy prime minister said, "Ours is a secular state.... Here every Muslim should feel that he is an Indian citizen and has equal rights as an Indian citizen" (Chandra, Mukherjee, and Mukherjee 1999: 78). Along similar lines, India's first Prime Minister Jawaharlal Nehru said during the early years of statehood, "In a country like India, which has many faiths and religions, no real nationalism can be built up except on the basis of secularity" (Nehru 1989: 163-64). A narrower approach, he argued, would result in disunity and 
reinforce communal sentiments and thereby prolong the old identity politics (ibid.). The secularism Nehru had in mind was not a "wall of separation" between the state and religion, but a doctrine of non-preference, which required that the state grant no special privilege to any one religion (Smith 1963: 381; Bhargava 2002: 12-14; Mahajan 2002). Instead, the state would keep a "principled distance" from all religions, and cultivate a "rational" approach to life free of customs considered unfit for a modern and democratic society (Bhargava 2002: 27). This Nehruvian notion of secularism has allowed the Indian state to not only support the activities of various religions equally (e.g., subsidies to Muslim pilgrims, Hindu temples, mosques), but also embark on a "civilizing mission" to abolish "backward" customs (such as untouchability), and to ascertain and rationalize the "religion" and "religious"-all in the name of social progress and national unity (Sathe 2003: 161-65).

Despite this "ameliorative" understanding of secularism, the post-1947 union governments largely refrained from extensive interventions into controversial religious matters through direct executive action or legislative means, other than personal status or family issues, such as cow-slaughtering or temple entry. Instead, they purposely left such issues to be dealt with by state governments and the judiciary, particularly the Supreme Court and provincial high courts (Dhavan 2001: 314; Smith 1963: 235-62). ${ }^{3}$ This aversion to dealing with controversial religious issues at the federal level largely reflected Nehru's conviction that the entanglement of politics and religion would only result in further communalization of politics and undermine the secular nationbuilding project (Chakrabarty 2008: 172). But Congress-dominated union governments' noninterference in controversial religious issues had also to do with the political conundrum that the ruling party faced regarding the Uniform Civil Code (UCC). Article 44 of the 1950 Constitution directed the government to replace religion-based personal laws with a civil code applicable to all Indians regardless of religious affiliation.

Both action and inaction on Article 44 had a political cost for the Congress Party. After the Hindu Code Bill reforms of 1955-1956, the next logical step would have been to either reform the laws of religious minorities or submit all Indians to one uniform civil law. The latter was deemed by some members of the government, including Prime Minister Nehru and the nation's first Minister of Law Ambedkar, to be essential for the creation of a civic national identity that would replace "divisive" communal attachments. However, the Indian Muslim community, which historically had supported the Congress and its allies in the elections, adamantly opposed the idea of a UCC, while the Hindu majority demanded its immediate implementation. This created a major dilemma for the Congress Party: if it had tried to

\footnotetext{
${ }^{3}$ As we will discuss presently, the main exceptions to this are the 1955-1956 Hindu Code Bill reforms (Sezgin 2013).
} 
unilaterally impose a UCC, it would have cost the party the so-called "Muslim vote" and possibly provoke the minority into rebellion (Rana 2006: 37; Rao and Rao 1974: 383). Conversely, if it had opposed introduction of a UCC, this would have cost them the support of conservative Hindu voters, and played into the hands of right-wing opposition parties, which repeatedly accused Congress' leaders of sacrificing national unity for the sake of appeasing the Muslim minority (Cossman and Kapur 2001: 53-80; Pantham 1997: 528-29). Thus, to no one's surprise, Congress-led governments, desiring to co-opt the Muslim minority and avoid further aggravating their strained relationship with Pakistan, developed a strong preference against legislative measures focused on religion (Hasan 1994: 61-63). This, combined with the common law tradition with its historical emphasis on courts and litigation (and the emergence of public interest litigation in the early 1980s), gradually led to a shifting of major decisions on religious regulation from the legislature to the judiciary (Moog 1998: 420).

In fact, as a direct legacy of British rule, the Indian courts began as early as the 1940s to entertain such questions as, "Who is a Hindu or Muslim?" or "What constitutes 'true' tenets of Islam and Hinduism?" Particularly so in cases where the judges were asked to rule on issues of personal law, conversion, and the constitutionality of provincial laws regulating temple entry and educational institutions. In the process, judges were asked not only to act as "theologians" and make "roving inquiries about all or any religious texts, beliefs, or practices" (Dhavan and Nariman 2000: 260), but also to shoulder the burden of "actualizing the vision of the makers of the constitution to bring about renaissance or reformation"- - a burden that was forced upon the judiciary by the politicians, who were constrained by ballot box considerations (Sathe 2003: 164). Against this backdrop, in the next section we look at how the Indian Supreme Court and the provincial high courts have dealt with religion within a secular democratic constitutional framework, and analyze the impacts of the judicialization of religious issues on inter-communal relations and Indian identity politics at large.

\section{"Semitization" of "Gentooism": The Indian Judiciary on Hinduism and Hindu Identity}

Is Hinduism a religion? If so, what are its main tenets? Is there a holy scripture in Hinduism that can be relied upon to extract canonical laws to apply in courts? These were the questions that colonial rulers and magistrates encountered in British India. Their solution was to forcibly impose monotheistic and what scholars have called "Semitic" categories of "religion" and "law" upon the diverse traditions of India. "Dharma" was reduced to the monotheistic notion of "religion," and the term "Hinduism" was invented and constructed as the belief system of "gentoos" - natives who practiced non-Abrahamic religions (Menski 2003; Smith 1998). In this process, colonial authorities, particularly the courts, undertook the Semitization of Hinduism and the construction 
of Anglo-Hindu law based on often-flawed assumptions about the place of dharmasastras within Hinduism. ${ }^{4}$

A systematic analysis of Supreme Court and high court cases ${ }^{5}$ for the period of 1947-2010 shows that after independence Indian courts not only inherited colonial notions of law and religion, and but also embraced the colonial administration's essentialist views about "true" tenets of Hinduism, and perpetuated its policy intended to reify and reform the Hindu tradition for both practical and political reasons (Pennington 2005: 167-90; Rocher 2010: 78-88). In the eyes of the British, "Hinduism" as a religion historically failed to produce a unitary system of discourse or institutional practices. This notion that Hinduism lacked unity and cohesiveness and that there was an urgent need for unification and homogenization found broad acceptance within in the Indian judiciary. It not only had the potential of making the daily task of adjudicating religious questions relatively manageable, but also catered to secularist and nationalist judges' desires to affect a wholesale sociolegal transformation within the Hindu community. For example, in response to the question of "who [are] Hindus and what [are] the broad features of Hindu religion," justices of the Supreme Court in the Satsang case (Sastri Yagnapurushadji v. Muldas Bhudardas Vaishya 1966) said they found it particularly difficult to define the Hindu religion or even adequately describe it due to the aforementioned lack of unity and fluidity of the tradition. "The Hindu religion," justices argued, does "not claim any one prophet; not worship any one God; not subscribe to any one dogma...." For the court, Hinduism was so elusive and diverse that its adherents did not even worship the same idols: "there are certain sections of the Hindu community which do not believe in the worship of idols; and as regards those sections which believe in the worship of idols, their idols differ from community to community." Similarly, ten years later, in Commissioner of Wealth-Tax, Madras v. Late R. Sridharan (1976), the Supreme Court declared, "Hinduism embraces within itself so many diverse forms of beliefs ... and worship that it is difficult to define the term 'Hindu' with precision."

Justices in both the Satsang (1966) and Sridharan (1976) cases, who deemed this state of affairs undesirable for practical and ideological reasons and seemed determined to overhaul it, argued that there were still "certain broad concepts" that could be treated as basic tenets of Hinduism (Rao 2004: 388). Solely relying upon English language sources, the justices identified

${ }^{4}$ By Semitization we refer to the process of reconstructing a polytheistic or non-theistic belief system along the lines of the major monotheistic Abrahamic religions to emulate their structural, theological, and ritualistic characteristics and build a "uniform" belief system. See Hansen (1999: 60) for information on the Semitization of Hinduism.

5 The rulings were identified conducting keyword searches in the Manupatra database for key terms, including "religion," "religious identity," "sect," "denomination," "secularism," "personal law," and "uniform civil code." 
the so-called "basic" tenets of Hinduism in a monotheistic fashion. The list provided in the Satsang case included "the acceptance of the Veda as the highest authority," as well as acceptance of the "great world rhythm" and belief in "rebirth and preexistence" (Galanter 1989: 243-44). In doing so, the court primarily presented Brahmanical notions as the ideal form of Hinduism in which the ultimate goal of humanity was defined as Nirvana, or "the state of absolute absorption and assimilation of the individual soul with the infinite" (Sastri Yagnapurushadji v. Muldas Bhudardas Vaishya 1966).

In regard to questions of what constituted "true" Hinduism and who shall be considered a Hindu, the judiciary spoke in two distinct and seemingly contradictory voices. At times, it argued that Hinduism was a heterogeneous tradition that recognized that there was more than "one valid approach to truth and salvation" (ibid.), but at others, embracing a monotheistic tone, it spoke of "the ultimate goal" and "true teachings" of Hinduism. This seemingly paradoxical approach was reflective of the judiciary's attempt to play both religious reformer and secular nation-builder at the same time. It inherited the colonial administration's reformist approach toward Hinduism, which also closely resonated with the nationalist leaders' (Nehru's and Radhakrishnan's) philosophical views and inclusivist stance toward Hinduism, which sought to "homogenize" and ascertain the Hindu tradition and "cleanse" it of its "repugnant" customs such as untouchability, and devadasi (Minor 1999: 16; Sen 2010). Following the precedents set by the colonial courts, the post-independence judiciary gradually transformed itself into a "supreme religious authority" that not only determined what the basic tenets and teachings of Hinduism were, but also gave it a modernist and secularist facelift by ridding it of what the judiciary saw to be its superstitious and non-egalitarian ethos (Indra Sawhney v. Union of India 1992). In the recent case of Sunni Central Board of Waqfs v. Gopal Singh Visharad (2010), the court went so far as to establish where Lord Ram was born-disregarding the state of historical research on the question, which has overwhelmingly concluded that the source material is too thin to affirm even his historical existence, let alone where he may have been born.

The judiciary has been also strongly committed to the principles of Nehruvian secularism and the goal of creating a composite Indian nation-with salient Hindu majoritarian contours - through the elimination of communal distinctions (Minor 1999: 15-16). In Pannalal Bansilal Pitti v. State of Andhra Pradesh (1996), the Supreme Court expressed its commitment to this assimilationist vision of nation-building: "The founding fathers ... were confronted with problems to unify ... people of India professing different religious faiths.... [They] provided a secular Constitution to integrate all sections of the society as a united Bharat. The directive principles of the Constitution [i.e., Article $44]$... attempted to foster uniformity among people of different faiths."

In accordance with its goal of attaining national unity through means of legal unification, particularly in the absence of a UCC, the judiciary adopted 
a piecemeal approach and pushed for maximum normative unity within each community. Its rhetoric of diversity must be understood against this background. By defining Hinduism as elusively and broadly as possible, the court aimed to include all "gentoos" under the Hindu fold and subject them to the purview of Hindu law. The Supreme Court's ruling in the Sridharan (1976) case provides a particularly good example of how justices used the rhetoric of diversity to construct a "universal" Hindu identity: "The term 'Hinduism' has been defined as meaning 'the civilization of Hindus.' ... Hinduism incorporates all forms of belief and worship without necessitating the selection or elimination of any.... A Hindu may embrace a non-Hindu religion without ceasing to be a Hindu...."

The judiciary's views on "who shall be considered a Hindu" were, in large part, in consonance with the particular vision of Hindu identity put forth by the framers of the constitution. The constitution-makers, who according to the bench in the Satsang (1966) case were fully conscious of the "broad and comprehensive character of Hindu religion," inserted an explanation to Article 25 to the effect that its references to Hindus would also include persons professing the Sikh, Jain, or Buddhist religions. In line with this constitutional provision, the Hindu Code Bill of 1955-1956 further expanded the definition of the Hindu fold by including within it any person who was not a Muslim, Christian, Parsi, or Jew. Despite the opposition by non-Hindu minorities who were forcibly included in the Hindu fold for purposes of personal law (e.g., Sikhs), the judiciary has often been oblivious to their demands and has consistently held the view that Sikhism, Jainism, and Buddhism were merely reform movements within Hinduism. ${ }^{6}$ All in all, as Sen eloquently argues, this propensity of the Indian judiciary toward homogenization has largely, and paradoxically, reinforced the Hindu right's "dual project, unifying and monotheizing Hinduism on the one hand, and subsuming all religions under the umbrella of Hindutva as a way of life on the other," and has escalated communal schisms and deepened minorities' fears of forced assimilation (2010: 199).

\section{The Indian Judiciary on Islam and Muslim Identity}

When dealing with such questions as "Who is a Muslim?" or "What are the defining practices of Islam?" the judiciary adopted an approach that closely resembled its stance on Hindu identity and tradition. Acting literally as a theological authority, the judiciary similarly attempted to "unify" the Muslim fold, "reform" Islam, and prepare Muslim public opinion for the eventual abolition and replacement of Muslim personal law with a UCC.

\footnotetext{
${ }^{6}$ See Sastri Yagnapurushadji v. Muldas Bhudardas Vaishya (1966); Shuganchand v. Prakash Chand (1961); Mahadvappa v. Chanabasappa Purad (1964); and Bal Patil and Anr. v. Union of India (2005).
} 
Who was a Muslim, or whether a particular group belonged to the Muslim fold, were questions that the judiciary was frequently asked to respond to. For instance, in Shihabuddin Imbichi Koya Thangal v. K. P. Ahammad Koya (1970), the defendant, a Muslim woman, claimed that her husband's conversion to the Ahmadi faith was an act of "heresy," and therefore her marriage to him should be considered void under Islamic law. In order to consider the claim, the justices of the High Court of Kerala had to decide whether the defendant's husband should still be considered a Muslim after joining the Ahmadiyya. First, the bench identified the "belief in the oneness of God" and "acceptance of the Prophet Mohammad as the last of the Prophets" as Islam's fundamental tenets. By necessary implication, then, the justices concluded, "the great teachers who came after [Mohammad] could not be exalted to the position of Prophet." So, they asked, "Is [this] the touchstone by which the [Ahmadis] can be put out of the fold, for they treat Mirza Gulam Ahmad as a Prophet, thus repudiating the second article of faith?"

The bench subsequently ruled that Ahmadis were merely a "reformed sect" within Islam. The bench in its reasoning adopted a "rationalist" methodology reminiscent of its policy toward Hinduism: "In science, discoveries are never treated as final and so Newton was disproved by Einstein and Einstein was modified by Sudarsan.... [Likewise, i]n the major religions ... subprophets do appear to revive, never to repudiate.... Thus, it is clear that Ahmad claimed to be a prophet, not a plenary one but secondary to the Holy Prophet.... Every religion has produced from time to time men of light and learning who ... contributed spiritually to the upgrading of the human personality.... [Thus, ] ... the [Ahmadiyya] sect is [part] of Islam and not alien (ibid.)."

In this "linear" reading of the Islamic thought and history, by introducing the idea of "sub-prophethood," which most mainstream Muslims would, and have, considered abominable, the court considered the Ahmadiyya as a reform movement within Islam that simply revived and improved on the message of Prophet Mohammad in the same way Einstein's theory of relativity improved on Newtonian mechanics. However questionable its methodology and reasoning was, the Kerala court's decision to include the Ahmadiyya in the Muslim fold was in accord with the post-independence Indian judiciary's position on Muslim identity. As in cases regarding Hindu identity, the judiciary, in quest for legal uniformity and certainty, systematically expanded the bounds of the Muslim fold, and brought members of all "anomalous" Muslim sects (e.g., Khojas, Bohoras, Cutchi Memons) under the purview of "Anglo-Mohammedan" law. ${ }^{7}$

Reminiscent of its policy to promote a homogenous, tolerant, and humanist version of Hinduism - building upon a philosophical foundation laid down by Radhakrishnan (Minor 1982) - the judiciary has also dabbled in Islamic

\footnotetext{
${ }^{7}$ For example, Fidahusein v. Mongbibai (1936); The Controller of Estate Duty, Mysore, Bangalore v. Haji Abdul Sattar Sait (1972).
} 
exegesis and hermeneutics in order to promote a "modern," "humanist," and "tolerant" vision of Islam and Muslim law, and truncate its socially disagreeable elements (e.g., polygyny, triple talaq, cow-slaughtering). For example, according to the High Court of Kerala, to consider the Shamsiya Thareeqath, a Muslim sect, un-Islamic and to prevent its members from entering mosques for prayer was "against the [sunna] of the Holy Prophet," who allowed even Christians "to perform their prayers according to their rituals" at his mosque in Medina (P. P. Puthiyanal Attakoya Thangal v. Union Territory of Lakshadweep 1987). Similarly, in the case of Lily Thomas v. Union of India (2000) justices of the Supreme Court argued that petitioners' views about permissibility of bigamy under shari 'a not only demonstrated their "ignorance" of the true meaning and tenets of Islam, but also unjustly imposed a narrower view upon a "pious, progressive, and respected religion with rational outlook."

The judiciary has occasionally acted further like a theological authority and passed "fatwa-like" rulings stipulating what the intention of the "enlightened Muslim community" regarding deceitful conversions should be (Smt. Sarla Mudgal, President, Kalyani v. Union of India 1995); which Islamic rituals and observations should be regarded as "essential" (Mohammed Hanif Qureshiv. State of Bihar 1959; the State of West Bengal v. Ashutosh Lahiri 1994); what architectural and structural elements would make a building a "proper" mosque (Sunni Central Board of Waqfs v. Gopal Singh Visharad 2010); and even how to read and interpret the Qur'an. The most spectacular example of such fatwa-like rulings was delivered in the Shah Bano case (1985), which has been comprehensively discussed in the literature. The all-Hindu bench of the Supreme Court was asked whether a Muslim husband had an obligation beyond the iddat period to provide maintenance for his divorced wife who was unable to sustain herself. "There can be no greater authority on this question than the Holy Qur'an," declared the bench. It cited both Arabic and English versions of chapter II, verses 241 and 242, and then continued: "[The verses] show that ... there is an obligation on Muslim husbands to provide for their divorced wives [beyond the iddat period]." The judges declared that arguments to the contrary did less than justice to the Qur'an. And if the all-Hindu bench had not sufficiently offended the Muslim sensibilities by telling Muslims how to read their scripture (Mitra and Fischer 2002: 119), it also concluded that there was an urgent need for reform in Muslim law; and if the community was unwilling to reform its laws, then the state had to take the lead by enacting a UCC for the entire country. But since the government lacked the "political courage" to enact such a code, justices noted, "The role of the reformer had to be assumed by the courts."

Despite occasional deviations in its tone, ${ }^{8}$ in a series of judgments from Shah Bano (1985) to John Vallamattom (2003), the Supreme Court has

\footnotetext{
${ }^{8}$ For example, in Madhu Kishwar v. State of Biar (1996), the court had watered down its stance on legal uniformity and ruled in favor of maintaining tribal and customary laws. Similarly, in Danial
} 
maintained that a UCC is imperative "both for the protection of the oppressed and the promotion of national unity and solidarity" (Smt. Sarla Mudgal, President, Kalyani v. Union of India 1995). In these judgments, the court consistently blamed the Muslim community for a lack of legal uniformity and the endurance of communalism. For instance, the bench in the Sarla Mudgal case argued that while the Hindus along with Sikhs, Buddhists, and Jains had forsaken their sentiments and reformed their sacrosanct laws for the cause of national unity, Muslims had stubbornly refused to do the same. They were, therefore, responsible for the failure of the secular nation-building project.

In the era following the end of Indira Gandhi's Emergency Rule (19751977), the Indian courts embraced a more activist and assertive stance. In Dhavan's words, in the 1980s the judiciary "ceased to be an institution of state" and "became an institution of governance in its own right" (2007: 84). Apart from the judiciary's rising assertiveness, the 1980s also witnessed a weakening of national consensus on Nehruvian secularism and the rise of right-wing nationalist Hindutva groups and discourses across the political landscape. During this new era of judicial activism, coupled with groundbreaking ideological transformations that, some argue (Das 2000: 17; Rao 2004: 406-8), caused the politically-leaning judges to swing to the right, the Indian courts embraced a visibly assertive and controversial approach in dealing with Muslim law and identity. For example, as seen in the Shah Bano case, from 1985 onwards the judiciary adopted a "lexicon" increasingly similar to those of right-wing Hindu groups (e.g., the Bharatiya Janata Party). These groups ran on an anti-minority platform, appropriated the concept of a UCC to serve their own ideological goals, and strongly criticized the Muslim institutions and community for a lack of loyalty to the Indian nation and secularism.

In the 1990s, the Supreme Court in several landmark decisions used the term "united Bharat" to underscore its commitment to creating a uniform national identity. ${ }^{9}$ The term "Bharat," however, is not a neutral conceptfrom the perspective of Hindu fundamentalists, it refers to the nation-state of those "who are encompassed by the concept of Hindutva [the core ethos of Hindu fundamentalism]" (Stump 2000: 196). Judges who were both ideologically and pragmatically driven, and who sympathized with right-wing Hindu groups, believed that "Hinduism offer[ed] the most viable plank on which the diverse elements of the nation [could] be united" (Rao 2004: 406). Judges

Latifi v. Union of India (SC), 2001, the court somewhat diluted its firm stance on personal laws (Sen 2010: 143-50).

${ }^{9}$ See Dr. D. C. Saxena, Contemnor v. Hon'ble the Chief Justice of India (1996); Ahmedabad Municipal Corporation v. Nawab Khan Gulab Khan (1996); and State of Uttar Pradesh v. Dr. Dina Nath Shukla (1997). 
who shared such views rarely missed an opportunity to engage in controversial ideological debates by needlessly resorting to lengthy obiter dicta about secularism, and the need for a UCC or national integration (Agnes 2007: 300-5; Rao 2004: 406). One of the leading members of this new cadre of justices was J. S. Verma of the Supreme Court, who infamously described Hindutva as a "synonym of Indianisation, i.e., development of uniform culture by obliterating the differences between all the cultures co-existing in the country" (Dr. Ramesh Yeshwant Prabhoo v. Prabhakar Kashinath Kunte 1996). ${ }^{10}$

Against this background, the Muslim minority understandably interpreted the judiciary's repeated calls for reform in Muslim laws and enactment of a UCC as a euphemism for the imposition of Hindu law upon non-Hindu minorities. They grew more insular and protective of their communal identity, and resistant to the idea of change in their laws (Mahmood 1995). Judicial decisions from Shah Bano (1985) to Lily Thomas (2000) and John Vallamattom (2003), which demanded reformation of Islamic law or the enactment of a UCC in the name of legal and national unity, fueled the already tense relations between the communities and escalated identity politics. In the eyes of the Muslim minority, the decisions turned the courts into willing allies of the Hindu right. The Muslim community, or forces who claimed to act on its behalf, responded to the challenge posed by the judiciary by setting up informal Islamic courts (Darul Qazas). These have actively discouraged Muslims from using state courts in matters of private law and have greatly contributed to the re-confessionalization of the Indian legal system. In recent years, the government and the judiciary have formally acknowledged the jurisdiction of these "informal" shari 'a courts, and have often recognized their decisions in the courts of law as arbitration rulings. Today, nearly sixty years after Article 44 found its way into the constitution, the defining characteristics of the Indian legal system are fragmentation and identity politics, and communal notions of law rather than nation-wide uniformity and universality. Ironically, the attempt at secular nation-building and legal unification failed not least because judicialization has de facto elevated specifically Hindu culture to a national culture rather than promoting a "culture of India" that transcends religious and linguistic particularity. Against this distinctively "Hindu" notion of "Indianness" and aims of legal uniformity, minorities have reasserted the right to their own particularity, especially with regard to law.

BUREAUCRATIZATION: A “PAN-RELIGIOUS” INDONESIAN STATE RESPONDS TO QUESTIONS OF RELIGION AND RELIGIOUS IDENTITY

After independence in 1945, the Indonesian leaders faced the same questions as did India's founders: What kind of state should Indonesia become? And should

\footnotetext{
${ }^{10}$ For further information on Justice Verma and a detailed analysis of his rulings, see Jacobsohn (2003: 189-226).
} 
the state be based on a core ethos? Like India, Indonesia was a multi-religious, multilingual, and pluri-legal society. In addition to Islam and Christianity, ancient traditions of Buddhism, Hinduism, and Confucianism, as well as several hundred indigenous belief systems existed across the archipelago. In the process of state- and nation-building, the founding elite decided that in order to overcome existing schisms and attain national unity they had to do away with the fragmented colonial legal system, which, they believed, was unfit for a unitary modern nation-state. ${ }^{11}$

Of particular concern to the founders was the question of what role religion, especially Islam, should play in independent Indonesia. After centuries of colonial rule, here was a chance to create a state where Islam would be the primary source of law, yet the vast cultural diversity across the archipelago would make a shared and uniform understanding of Islamic law difficult. Moreover, the proclamation of an Islamic State (Negara Islam) could provoke nonMuslim islands in the East to secede. Ultimately, the final version of the 1945 constitution declared not an Islamic but a state with equal citizenship for Muslims and certain non-Muslim groups alike. ${ }^{12}$ Members of the constitutional drafting committee felt strongly that the state should nevertheless have an ethical mandate, even if not an explicitly Islamic one. A list of five ethical principles was adopted in the preamble that committed Indonesians to: (1) "the belief in the one and only God"; (2) a "just and civilized humanity"; (3) unity of the country; (4) democracy "guided by the inner wisdom of unanimity arising out of deliberations among representatives"; and (5) social justice.

These five principles, called "pancasila"-notably Sanskrit rather than bahasa Indonesia or Arabic-were developed by the nationalist leader Sukarno, who later became the country's first president. Muslim modernists in principle accepted Sukarno's pancasila, but demanded that the first principle be accompanied by a clause stipulating the implementation of Islamic law: Belief in one God with the obligation to implement the shari'a for adherents of Islam. This supplementary clause, which came to be known as the Jakarta Charter, was accepted in the drafting committee on 22 June 1945. However, by the time the committee reconvened to sign the constitutional preamble on 18 August, the Jakarta Charter had been omitted from the final version.

11 While, as mentioned, we focus our analysis on the Old Order (1945-1966) and New Order (1966-1998), it would be worthwhile to explore the consequences of democratization and decentralization on state policy toward religion. The 2001 decentralization law granted some five hundred regencies the right to pass laws of their own. De jure, these laws must cohere with national law and the constitution, but de facto, they often violate the principle of religious freedom. Since many of these laws are currently contested in the high courts of the country, or are no longer enforced due to their contested legality, it is too early to assess the possible long-term effects of these sub-provincial laws for the question of nation-building and the unity of the legal system. For preliminary analyses, see Parsons and Mietzner (2009) and Bowen (2013).

12 For the complicated back and forth on the question of religion and Islamic law between different factions in the constitutional drafting bodies in 1945, see Kusuma and Elson (2011). 
After the Jakarta Charter was dropped, Islamic groups temporarily withdrew their support from the national government. Only the appearance of the Allied powers in 1945 and the consequent attempt by the Netherlands to reoccupy the country swayed them to renew their loyalty to Jakarta. Reluctantly, regional elites who had hoped for the establishment of an Islamic state complied with the new constitution, fully expecting that within a year or two countrywide elections for a constituent assembly would take place and a new constitution would be drafted that replaced the pancasila state with an Islamic state.

Amid the war of independence against the Dutch from 1945-1949, the elections originally planned for January 1946 were not held until 1955. Even once the constituent assembly was elected in 1955 and deliberated over a new constitution between 1956 and 1958, the two-thirds majority needed to turn Indonesia into an Islamic state could not be reached. By 1959, President Sukarno had grown so frustrated with the inability of the Konstituante to reach a consensus that he reinstated the 1945 constitution and reaffirmed pancasila without the Jakarta Charter, without, that is, the duty for Muslims to abide by Islamic law. The unitary, non-Islamic, but pan-religious formula that had been adopted in 1945 henceforth became the most characteristic feature of the country's post-independence political system.

\section{The Policy of Agamasasi: Turning Religion into the Building Block of Indonesian National Identity}

Pancasila proved very useful in providing a pan-religious national ethos to a pluralistic society, and could have been a window of opportunity for positive and negative religious freedom. However, this potential freedom was soon undermined by the Indonesian state's policy of requiring religions to be recognized as such by the state. With this approach, the Indonesian policy toward religion closely resembled that of Japan, where Shintoism was elevated to a pan-religious national ethos, and religious communities had to fit governmentdefined categories to avoid being shut down (De Bary et al. 2006: 118-21; Hardacre 1989). Being an adherent of a state-recognized religion (agama) became a requirement for citizenship. Those Indonesians who did not profess an agama were referred to as "orang yang belum beragama," people who do not yet have a religion, "implying that they would need to adopt an agama if they were to become full participants" in the new state (Chalmers 2006: 125). Official identification cards listed religious affiliation and Indonesians who wanted to enter the military or public service needed to prove they belonged to a state-recognized agama. In political and legal usage, agama or a state-recognized religion was distinguished from kepercayaan, non-theistic belief systems (Aragon 2000: 15, 33, 325; Chalmers 2006: 125; Schrauwers 2000: 57). 
Unlike the Indian state, which delegated the controversial task of delineating what a religion was to the judiciary, the Indonesian government followed the Japanese model and entrusted the task to the bureaucracy. The elevation after independence of the Japanese-founded Office of Religious Affairs into a full ministry was originally viewed as a concession to organized Islam in exchange for Islamic groups' political support of the central government. As such, the MORA was distrusted by the Sukarno administration's more secularminded members. Yet it soon evolved into one of the largest ministries, and increasingly proved useful for putting organized Islam into the service of consolidating the power of the central administration. In this way the ministry came to play an important role in the nation-building process (Emmerson 1978; Geertz 1960: 212; Lev 1972: 49-56).

While the MORA channeled funds into private religious schools and subsidies to hospitals run by the country's large Islamic organizations, the ministry also increasingly came to "manage" religion. In 1952, it passed a regulation (no. 9 of 1952, Article VI) which required that, for a community to be recognized as having a religion (agama), it had to profess an internationally recognized monotheistic creed with a holy scripture, embrace the idea of prophethood, and adhere to universal ethical teachings (i.e., teachings not exclusive to a particular race, tribe, or ethnicity) (Atkinson 1987; Kipp and Rodgers 1987; McDaniel 2010: 96; Ramstedt 2004b: 9). ${ }^{13}$ At that time, all other faiths, which did not fit the strict ministerial definition, were referred to as aliran kepercayaan, or "currents of belief." The 1952 regulation explicitly rejected non-theistic belief systems, including Hinduism, Buddhism, Confucianism, and other indigenous religions, and referred to them as "dogmatic opinions that belonged to tribes which were still backward" (Ramstedt 2004b: 9).

The MORA initially recognized three religions: Islam, Protestantism, and Catholicism. If adherents of kepercayaan (currents of belief) wanted to become full members of a "progressive nation," they had to homogenize and rationalize their belief systems along monotheistic lines. The adherence to a belief system determined to not only hamper the nation's progress but also openly clash with pancasila was incompatible with full membership in the political community (ibid.). In 1958 Hinduism, and in 1965 Buddhism and Confucianism, were recognized, after each had undergone a state-induced process of "internal reform" along monotheistic lines (Howell 1982: 511-17). This internal reform required revivification and "reinvention" of ancient traditions, rituals, narratives, and texts, as well as prioritization of certain elements over others

\footnotetext{
${ }^{13}$ Because of opposition from Balinese Hindus, the 1952 definition of agama was later repealed, and replaced by another definition in 1961, which included as necessary elements a prophet, a holy scripture, the absolute lordship of Tuhan Yang Maha Esa (god), and a system of law (Intan 2006: 45; Mulder 1978: 4).
} 
so as to locate an omnipotent, omniscient, and omnipresent supreme deity, a holy scripture, and a prophet. ${ }^{14}$

Particularly instructive in this respect is the experience of Balinese Hinduism. In order to meet the MORA criteria, Hindu intellectuals rebuilt the entire Hindu belief system following a monotheistic model. To emphasize the "oneness of God," they promoted Brahman to the "supreme god" and gave him an Indonesian name, and turned other gods into his "angels" and "saints." The Vedas were declared the equivalent of the Qur'an or the Bible, and the Vedic sages (rishis) became "prophets." Collections of mantras were transformed into three-times-a-day prayers (Tri Sandhya), equivalent to Islamic salat (McDaniel 2010: 96-97; Ramstedt 2004b: 11-12). With its understanding of religion modeled on the Abrahamic religions, the MORA's agamasasi policy in its essence resembled the judiciary-sanctioned process of Semitization that we encountered in the Indian case (Hefner 2004: 97).

In Suharto's New Order (1966-1998), the activities and political role of the MORA grew steadily. It was placed under direct supervision of the President, who not only appointed his close allies to the ministry but also singlehandedly oversaw the formulation and implementation of its policies. The regime deemed the strict control of the ministry essential for fighting its so-called enemies within and without, particularly "communist and the Chinese instigators" (Surbakti 1991: 127-37, 366). Under the New Order, anyone who did not profess a recognized religion risked being identified as an atheist and by association a communist (O'Shaughnessy 2009: 169). More than half a million fell victim to the massive anti-communist pogroms that characterized the early years of Suharto's ascent (1965-1966).

The government forced many of those who originally adhered to the so-called aliran kepercayaan to either relinquish their "backward" faiths or transform them into a recognized agama. Between 1966 and 1980, mass conversions to Islam and Christianity, and to a lesser extent Buddhism and Hinduism, took place especially among adherents of indigenous belief systems (Ginting 2004: 226; Hefner 2004: 105; Ramstedt 2004a: 196; 2004b: 17). Communal conversions to the recognized agamas are reminiscent of the way the Indian judiciary homogenized heterodox religious communities by including them in the fold of Hinduism or Islam. As Schiller (1996) demonstrates in the case of the Ngaju indigenous religious community, Indonesian bureaucrats, like Indian justices, were inclined to interpret indigenous practices as varieties of Hinduism and Buddhism, and register their adherents as members of these

\footnotetext{
14 Confucianism (to which about 0.007 percent of Indonesians adhere) was removed from the list of recognized religions by a 1978 ministerial directive (Minister of Home Affairs Directive no. 477/74054/BA.01.2/4683/95 of 18 Nov. 1978). This took place against the backdrop of anti-Chinese policies during Suharto's New Order, which also prohibited the celebration of Chinese New Year and other Chinese festivities (Abalahin 2005; Heriyanto Yang 2005). Confucianism was only re-recognized as a religion when the ministerial directive was lifted in 2001.
} 
traditions in order to attain religious and cultural homogeneity and create the ideal Indonesian citizen: the "manusia pancasila"- the pancasila man or woman (O’Shaughnessy 2009: 169; Ramstedt 2004b: 17). By doing so, authorities not only converted people from an aliran kepercayaan to a recognized religion (agama), but also inducted them into Indonesian citizenship (Freston 2001: 81).

Thus, both India and Indonesia, following in the footsteps of their colonial rulers, undertook far-reaching processes of "Semitization" of their religions in the post-independence period. In both societies, religions were redefined and remodeled to fit state-defined categories mostly informed by monotheism, and citizens were forced to transform their religious practices to fit these "reformed" religions.

\section{Religion and Religious Law in Indonesian Courts}

Like their Indian counterparts, Indonesian leaders at the time of independence were keen to put an end to the multiplicity of legal systems and unite the nation under one law (Salim 2008: 75). Adat, or customary law, was particularly targeted due to its "feudal, imperialist and anti-republican connotations" and was gradually phased out and replaced by positive law (Lev 2000: 33-70; Lukito 2003; Ramstedt 2004b: 8). By the time the central state had prevailed over all the separatist struggles, in 1969, state courts had replaced the last customary courts. Islamic law, however, was more difficult to abolish. The state, fighting the war of independence, simultaneously fought secessionist movements across the islands that advocated the establishment of an Islamic state.

Islamic groups, marginalized since the dissolution of the Constitutional Assembly and the 1959 establishment of Sukarno's "Guided Democracy" (a coalition of nationalists, communists, and socialists), had assisted Suharto's military takeover in 1966 and participated prominently in the anti-communist pogroms of 1965-1966. Since the Muslim modernist party Masyumi had been banned by Sukarno in 1960, Islamist and Islamic leaders hoped for the revival of political Islam in Suharto's New Order. They were bitterly disappointed when Suharto upheld the ban on Masyumi and, in 1973, went so far as to "simplify" the party system by forcing remaining Islamic parties to merge into one of two regime-sanctioned opposition parties.

In compensation, Suharto gave in to two Islamist demands. In 1975, he set up the Indonesian Ulama Council (MUI), which gave representation to leading modernist thinkers and scholars and issued fatwas on urgent legal questions, including dietary issues. Secondly, Suharto and the military watered down a draft marriage law, which was eventually passed in 1974. In draft, the law would have made marriage exclusively a state matter by stipulating that "a marriage is valid if it is performed before an official marriage registrar" (Cammack, Young, and Heaton 2008: 301). As such, it remained in line with the postindependence project of legal unification that envisioned the replacement of 
all particularist law by one uniform and countrywide civil code (Butt 2008: 269). But in exchange for forcing Islamic leaders to accept the regime's exclusion of political Islam, Suharto and the MORA made a profound concession on the marriage law. In the final draft that was passed, it permitted an exception for Muslims: while all marriages of the non-Muslim population had to be certified in civil registries, the law left an opening for Muslim marriages to be certified by Islamic courts. In this way, the law recognized Islamic courts and signified a clear departure from earlier legal reform projects that foresaw the phasing out of religious courts and unification of the legal system.

The law also permitted two different legal standards on marriage. It distinguished between marriages that were "valid," and those that were "legal." The former were marriages that fulfilled the known standards of an Islamic marriage contract; to be "legal" from a civil law perspective, marriages had to fulfill the standards specified in the Marriage Law. For instance, the 1974 law prohibited polygyny for civil servants. For ordinary citizens, polygyny was made more difficult since it now required the written consent of the first wife accompanied by proof that she was unable to perform her duty as a wife. It also required the husband to prove that he had the material means to support more than one wife and their offspring. The 1974 law also required only the consent of the marrying parties, whereas the Islamic courts could continue to demand consent of the woman's legal guardian. They could also disregard the minimum marriage age set in civil law at eighteen for the woman, and twenty-one for the man.

As Islamic family law, beside the 1974 Marriage Law, remained uncodified, and rulings in the Islamic courts could differ significantly from one court to another, the MORA tried in the early 1990s to effect some standardization in the application of law. In 1991, it issued a Compilation of Islamic Law (Kompilasi Hukum Islam, or KHI), decreed per presidential instruction number 1 in the same year, which gave direction as to the most authoritative opinions and regulations that religious judges (hakim agama) ought to invoke. Strictly speaking, the compilation was not a code for hakims to follow, but it did narrow the range of interpretations available, and quickly replaced citations of the Islamic books previously used (classical books of Shafi i fiqh). This was especially important because the Religious Judicature Act of 1989 withdrew the existing possibility for civil registries to overrule hakim agama decisions, so that the Islamic courts now became full courts of first instance (Federspiel 1998). Though the New Order had still failed to make Islamic family law entirely a state issue, the court reform as well as the introduction of the Kompilasi Hukum Islam presented important steps toward the bureaucratization of Islamic law and the unification of Islamic jurisprudence across the archipelago (Mawardi 1998; Nurlaelawati 2010). Indeed, "religious court judges began to see themselves as part of the wide state bureaucracy and law enforcement apparatus, rather than as upholders of Islamic law" (Butt 2008: 274). 
The family matters of the other four recognized religions continued to be dealt with in the civil courts. Although the 1974 Marriage Law did not explicitly prohibit inter-religious marriages, it is often interpreted as so doing because it defined marriage as a contract carried out according to the religion of both parties (O'Shaughnessy 2009: 170). In another step to appease Islamic constituencies in exchange for political support, Suharto solidified the government's anti-inter-religious marriage stance in 1983 with a decree that de-authorized civil registries from registering mixed marriages where one partner was a Muslim. The 1991 Kompilasi Hukum Islam went a step further, and in Article 40-c, explicitly prohibited Muslim men from marrying non-Muslim women, directly contradicting the dominant Shafi'i position on the matter (Mawardi 1998: 61). The reason was pragmatic: the offspring of couples with a non-Muslim mother tended to adopt the mother's rather than the father's religion, and thereby contributed to the growth of non-Muslim religions in Indonesia.

The issue of inter-faith marriages demonstrates the sharp difference between India and Indonesia regarding the roles that their courts play in defining religion. Since there is no limit or penalty on individual religious conversion in Indonesia, barriers to inter-religious marriage are usually overcome by one spouse converting - at least for the letter of the law - to their partner's religion. Once partners have declared their shared religion, it is a simple matter to determine whether the marriage will be certified by a hakim agama or a civil registry. In contrast to India, courts are little concerned with establishing proof of the litigant's religious identity. In fact, as O'Shaughnessy demonstrates through her analysis of six inter-religious marriage and divorce cases from 1987 to 2003, courts have almost completely refrained from dealing with questions of religious identity (2009: 170-77). Instead, the courts have taken litigants' declared identity at face value and have not sought to determine its authenticity.

During the New Order, Indonesian justices were quite careful not to transgress the MORA's jurisdiction by openly discussing questions of ethnic, religious identity or inter-group relations (Kipp 1993: 110). ${ }^{15}$ This aversion seems to have become an institutional practice that continued even after the fall of the Suharto regime in 1998. For example, in the recent Wijaya-Guito case (2000), in which the litigants asked the Supreme Court to uphold the legality of their marriage conducted according to Confucian rites, justices explicitly stated that they were in no position to judge whether Confucianism was an agama, or if it had a supreme deity, a holy scripture, or a prophet. These

15 While the MORA has retained its role of regulating religion in Indonesia, even after democratization in 1998, the high courts have heard a number of cases involving religious laws, such as the Blasphemy Law, the Polygamy Law, the Religious Courts Law, and the Places of Worship Law (Butt 2010; Crouch 2012; Pausacker 2012). 
are questions that Indian justices find it hard to resist passing judgments on. But in the Indonesian case the bench accepted the couple's plea on the grounds that the 1974 Law explicitly recognized the validity of marriages conducted according to the parties' belief systems (Abalahin 2005: 140; Heriyanto Yang 2005: 5; Irianto 2005).

COMPARING INDIA AND INDONESIA: JUDICIALIZATION VERSUS BUREAUCRATIZATION

What explains the counterintuitive outcomes of the Indian and Indonesian approaches to religious policy? Why has India's policy of judicialization, contrary to expectations, not diffused but instead further escalated identity politics, while Indonesia's policy of bureaucratization has been comparatively successful in deflating inter-religious tensions?

We explain this apparent paradox by pointing to each country's particular choice of delegation (i.e., judicialization versus bureaucratization). Incumbents delegate certain functions to judiciaries or specialized bureaucratic agencies with the assumption that they will act in ways that will produce outcomes desired by the delegating authority. The benefits of delegation lie in the reduction of political transaction costs as well as the increased ability of the principals to shift the blame onto their agents for policy failures and unpopular but necessary decisions (Tallberg 2003: 26).

All acts of delegation are innately problematic, however, because agents' interests almost always diverge from those of their principals, and this eventually leads them to pursue their own preferences. In order to minimize the risk of non-compliance, principals need to establish effective institutions of control to monitor and sanction acts of their agents (ibid.: 28). Seen in this way, the stricter the control mechanism is, the lower the risk of defection will be. Here lies a major difference between the Indonesian and Indian experiences. Under the Sukarno and Suharto regimes, the Indonesian government delegated vertically to a lower-level agency, established a stricter mechanism of control over the MORA's bureaucracy, and successfully prevented it from pursuing policies that would diverge from the central administration's broader policy preferences. The Indian government, by contrast, delegated horizontally to the judiciary over which it lacked sufficient means of control. Therefore, the Indonesian MORA had relatively less discretionary power than did the Indian judiciary. Even though the MORA was originally created as a concession to co-opt Islamists, and generally distrusted by a national ruling elite wary of political Islam's growing power, it later grew into an agent that not only legitimized the ruling elite against its critics but also loyally served the political interests of the regime (Geertz 1960: 212; Lev 1972: 45-50).

After independence, the Indian politicians who, in contrast to nondemocratic Indonesia, were constrained by ballot box considerations, devolved 
the task of socio-religious reformation to the judiciary, especially the Supreme Court and the state high courts (Sathe 2003: 164-65). Sweet (2003) convincingly argues that when it comes to understanding the nature of delegation between the government and high courts that regulate the actions of the executive and legislature, the metaphor of "agency" is less appropriate than a metaphor of "trusteeship." That is because of political property rights and the greater degree of independence granted to the judiciary. Thus, the Indian high courts should not be understood as the agents of the government but rather as a fiduciary that has been granted extensive powers and authority to rule over questions pertaining to religion. In contrast to agents (such as the MORA in Indonesia), fiduciaries enjoy a much greater "zone of discretion," which is defined as the sum of powers delegated to them by the principal minus the sum of monitoring instruments available to the principal to constrain or reverse the actions of the fiduciary when it does not agree with them (ibid.: 82).

Especially in the early years of the republic, Indian judges, particularly at the top of the hierarchy, belonged to a social elite that shared similar political and ideological interests with the ruling elite (Dhavan and Nariman 2000; Moog 1998). In this respect, the early Congress governments perhaps considered the delegation of religious issues to a "reformist-minded" judiciary demonstrating a great deal of loyalty to the regime and constitutional principles both a politically sensible and cost-efficient move. However, in the postemergency era (after 1977) the high courts' preferences, particularly regarding such issues as secularism, the UCC, and personal laws, started to diverge from the political and ideological interest of the Congress governments, and often aligned with those of rising right-wing Hindu groups, which later, from 1998 to 2004, assumed the control of the national government (Jacobsohn 2003; Rao 2004). Apart from Rajeev Gandhi's government's attempt to reverse the Supreme Court decision in the Shah Bano case (1985), both the Congress and later Bharatiya Janata Party governments have refrained from interfering with the decisions of the Supreme Court and high courts, often due to the prohibitive costs of intervention. After all, a hallmark of democracy is the independence of the judiciary and its capacity to resist political and popular pressures.

Given the democratic nature of the post-independent Indian state, the hands of the government vis-à-vis the rulings of the judiciary were tied. In nondemocratic Indonesia, by contrast, where the ministries had little autonomy vis-à-vis the office of the president, policy toward religion could be directly folded into the larger nation-building project.

\section{ONCLUSIONS}

Despite democratic India's attempt to unify the country under one law and create a civic notion of "Indianness," its politics of religion has deepened ethno-religious schisms and contributed to the re-confessionalization of the Indian legal and political system. We have shown the extent to which the 
judiciary has gradually become involved in the ascertainment and regulation of religion, and how questions of religion have therefore become increasingly judicialized. In Sukarno's and Suharto's Indonesia, by contrast, policy toward religion was delegated to the bureaucracy rather than the judiciary. Like India's judges, Indonesian bureaucrats got involved in ascertaining and defining religion, notably in requiring of polytheistic Hinduism and Buddhism to fit into government-imposed monotheistic categories. In both societies then, the post-colonial state has been highly involved in "Semitizing" polytheistic religions and in defining their core tenets. In both states, much violence was done to religion, practices were redefined and "purified," and creeds were "rationalized" and standardized by the state, often to make them "modernist," "humanist," and "tolerant." In both countries, notwithstanding that India was a democracy and pre-1998 Indonesia an authoritarian system, these projects were legitimized in terms of progress, modernity, and national unity.

In India, the institutional and ideological legacy of British rule, combined with the Congress-led governments' aversion to dealing with religious questions within legislative and executive branches, led to increasing judicialization of all questions pertaining to religion. Here, the Indian judiciary became ever more activist and rarely shied away from ruling over matters of religious dogma or identity. However, as we have shown, the judiciary's meddling in religious affairs has contributed to an escalation of identity politics, emphasized group differences rather than commonalities among citizens, and undermined the legal unification project. What seems to have brought about this unexpected outcome is that the Indian judiciary tried to undertake a paradoxical task: it aspired to secularize and unify the nation and the legal system, while it also - in the absence of a UCC - pushed for maximum normative unity within each segment of the population and brought various heterodox groups into the recognized "Hindu" and "Muslim" folds. It thereby involved itself in creating and sustaining the very communal identities and attachments that it avowed to eradicate in the name of national and legal unity. As courts continuously pushed for uniformity and homogeneity within Islam and Hinduism, they gradually chipped away at the normative and theological diversity of these traditions and promoted a monolithic vision of each. Hence, from the very beginning, the judiciary, despite its secularist and rationalist intentions, paradoxically emerged as an inadvertent ally of Hindu nationalists (Sen 2010: xxxi) who long promoted a monotheized and uniform vision of Hindu religion and culture that would encompass all other religions and cultures of India (i.e., Hindutva) (Kopf 1979; Pennington 2005; Zavos 2002).

The ontological resemblance particularly between the Supreme Court's jurisprudence on Hinduism and the Hindu nationalist discourse became increasingly visible in the 1980s and 1990s. By then, even the Congress Party had backed away from its historical commitment to Nehruvian secularism and adopted a "soft" Hindutva platform to appeal to right-wing voters (Sathe 
2003: 174). As some have suggested, the judiciary was not immune to groundshaking ideological changes of the 1980s and 1990s. Some activists judges, perhaps for both ideological and practical reasons, began accusing minorities of disloyalty to the nation, and using the language of Bharat and Hindutva, directly borrowing from the lexicon of Hindu nationalism (Das 2000: 17; Jacobsohn 2003: 202-9; Rao 2004: 406-8). As a result, for many Indians, especially the Muslim minority, the judiciary, the inadvertent ally of the right-wing Hindu nationalism of the 1960s-1970s, seemed to have become a willing ally of the Hindutva nationalists in the 1990s, when the Bharatiya Janata Party and its allies systematically appropriated favorable Supreme Court rulings to legitimize their ideological positions and programs. The perceived close association of the judiciary with the nationalist camp, coupled with under-representation of Muslims in the judiciary (Sachar 2006), ${ }^{16}$ has increasingly turned the courts into distrusted alien institutions for the Muslim minority who came to view the judiciary as an instrument of Hinduization rather than a neutral promoter of secular ideals and a civic national identity. In the final analysis, the post-independence judiciary's simultaneous goals of secular nation-building and religious homogenization were antithetical.

By comparison, the post-colonial Indonesian state approached religious policy with a bureaucratic developmentalist outlook that mirrored the politics of the colonial administration, and appropriated religion for its own socio-economic and social engineering purposes. The Japanese State-Shinto inspired agamasasi project, which required citizens to identify with one of the state-recognized religions, some of which had to reform themselves along monotheistic lines, amounted to a major religious-engineering project. Agamasasi was intended to fight against communism, "to extirpate indigenous religions that do not easily support development, to meld and smooth over differences among Indonesian religions, to neutralize any influence that religious sects have to take issue with national platforms [and] to support the dissociation of religious and ethnic identities" (Aragon 2000: 312; Schrauwers 2000: 92). Thus, the policy was of central importance to reducing ethnoreligious heterogeneity and promoting a singular, monotheistic image of religion. The agamasasi project's effects were severe, forcing Indonesian citizens into one of five recognized religious categories, and the pan-religious ethos of pancasila, which cannot be identified with any one particular preexisting culture or religion, extenuated the communalization effects of agamasasi and projected a shared national identity.

In contrast to India, the national culture that the post-independent governments in Indonesia promoted were not unmistakably identified with one

\footnotetext{
${ }^{16}$ The under-representation of Muslims in the judiciary is not a product of the operation of the courts themselves, but rather of larger trends in society and governance relating to discrimination against Muslims (which the Sachar Committee documented).
} 
particular religion or ethnicity. While minorities in India increasingly interpreted the state's promotion of "Indianness" as a euphemism for promoting Hinduism as a dominant culture, no one viewed the national ethos of pancasila as a covert means of promoting Muslim-majority culture. In fact, Islamic intellectuals in post-independence Indonesia have historically seen pancasila to be in tension with "Islamic ways of life." That pancasila cannot be closely identified with any of the major religions of Indonesia has been, for the purposes of nation-building, a covert blessing since it has precluded the promotion of any particular preexisting religious culture under the banner of "Indonesianness." The MORA, under the direct supervision of the president, was in charge of formulating and implementing this vital policy. Due to the centrality of religious issues to nation-building and the ideological and political consolidation of the regime, the MORA was placed under strict control by the government. This prevented the bureaucratic drift that could have derailed the pancasila-centered nation-building project. The relationship between principal and agent, or fiduciary of the devolution of religious policy, is key to understanding why judicialization undermined India's nation-building project, while in Indonesia bureaucratization harmonized with the central government's intended policy.

Both India's process of judicialization and Indonesia's bureaucratization did much violence to religion, and to both religious and non-religious communities. One would be hard pressed to show that either process produced more democratic outcomes or resulted in fewer or less dramatic human rights violations than the other. Considering that in India the politics of religion has been part of the post-independence process of democratization and democratic consolidation, this raises serious questions as to whether the Indian judiciary has done more to undermine rather than bolster shared rights standards.

Bureaucrats, judges, and elected politicians in democratizing multicultural societies from South Africa to Burma have encountered religious questions very similar to those that Indian and Indonesian authorities have faced. How they respond to these and address the challenge of religious heterogeneity has a profound impact on prospects for nation-building and democratization. Accordingly, how scholars think about the consequences of the judicialization or bureaucratization of fundamental normative choices matters a great deal. A case in point is the recent debate in Egypt over whether or not Article 2 should be justiciable in a future, possibly democratic system. A democratic Egypt will require a politically autonomous judiciary. At the same time, a justiciable Article 2 may in the medium to long term enable that judiciary to become the primary motor for Islamizing legal reforms. Therefore, before scholars engage, implicitly or explicitly, in recommendations as to the role of religion in democratizing societies, and where this role should be negotiated, the consequences of different means of delegating religious questions must be studied using more sophisticated comparative taxonomies. Rao (2004), and Ginsburg and Moustafa (2008), have laid solid groundwork for such a research 
design, but scholars have yet to address how these different consequences are shaped by varying relationships between principals and agents. We hope that our article will instigate this urgently needed comparative project.

\section{REFERENCES}

Abalahin, A. J. 2005. A Sixth Religion? Confucianism and the Negotiation of Indonesian Chinese Identity under the Pancasila State. In A. C. Willford and K. M. George, eds., Spirited Politics: Religion and Public Life in Contemporary Southeast Asia. Ithaca: Cornell University Press, 119-42.

Agnes, F. 2007. The Supreme Court, the Media, and the Uniform Civil Code Debate in India. In A. D. Needham and R. Sunder Rajan, eds., The Crisis of Secularism in India. Durham: Duke University Press, 294-315.

Aragon, L. V. 2000. Fields of the Lord: Animism, Christian Minorities, and State Development in Indonesia. Honolulu: University of Hawai i Press.

Atkinson, J. M. 1987. Religions in Dialogue: The Construction of an Indonesian Minority Religion. In R. S. Kipp and S. Rodgers, eds., Indonesian Religions in Transition. Tucson: University of Arizona Press, 171-86.

Benda, H. J. 1958. The Crescent and the Rising Sun; Indonesian Islam under the Japanese Occupation, 1942-1945. The Hague: W. van Hoeve. Distributed by the Institute of Pacific Relations.

Bhargava, R. 2002. What Is Indian Secularism and What Is It For? Indian Review 1, 1: $1-32$.

Bowen, J. 2013. Contours of Shari'a in Indonesia. In M. Künkler and A. C. Stepan, eds., Democratization and Islam in Indonesia. New York: Columbia University Press, 149-67.

Butt, S. 2008. Polygamy and Mixed Marriage in Indonesia: Islam and Marriage Law in the Courts. In T. Lindsey, ed., Indonesia: Law and Society. Singapore: ISEAS, 266-87.

Butt, S. 2010. Islam, the State and the Constitutional Court in Indonesia. Pacific Rim Law and Policy Journal 19, 2: 279-301.

Cammack, M., L. A. Young, and T. Heaton. 2008. Indonesia's Marriage Law. In T. Lindsey, ed., Indonesia: Law and Society. Singapore: ISEAS, 288-312.

Casanova, J. 2006. Rethinking Secularism: A Global Comparative Perspective. Hedgehog Review, 8, 1-2: 7-22.

Chakrabarty, B. 2008. Indian Politics and Society since Independence: Events, Processes and Ideology. London: Routledge.

Chalmers, I. 2006. Indonesia: An Introduction to Contemporary Traditions. Oxford: Oxford University Press.

Chandra, B., A. Mukherjee, and M. Mukherjee. 1999. India after Independence. New Delhi and London: Penguin Books.

Cossman, B. and R. Kapur. 2001. Secularism's Last Sigh?: Hindutva and the (Mis)rule of Law. Delhi: Oxford University Press.

Crouch, M. A. 2012. Law and Religion in Indonesia: The Constitutional Court and the Blasphemy Law. Asian Journal of Comparative Law 7, 1: 1-46.

Das, G. 2000. The Supreme Court: An Overview. In B. N. Kirpal, A. H. Desai, and G. Subramanium, eds., Supreme but Not Infallible: Essays in Honour of the Supreme Court of India. New Delhi: Oxford University Press, 16-47.

De Bary, W. T., C. Gluck, A. E. Tiedemann, W. J. J. Boot, and W. M. Bodiford. 2006. Sources of Japanese Tradition, Part II (1868-2000). 2d ed. New York: Columbia University Press. 
Derrett, J. D. M. 1999. Religion, Law and the State in India. Delhi: Oxford University Press.

Dhavan, R. 2001. The Road to Xanadu: India's Quest for Secularism. In G. J. Larson, ed., Religion and Personal Law in Secular India: A Call to Judgment. Bloomington: Indiana University Press, 301-29.

Dhavan, R. 2007. Governance by Judiciary: Into the Next Millennium. In B. D. Dua, M. P. Singh, and R. Saxena, eds., Indian Judiciary and Politics. New Delhi: Manohar, 73-106.

Dhavan, R. and F. S. Nariman. 2000. The Supreme Court and Group Life: Religious Freedom, Minority Groups, and Disadvantaged Communities. In B. N. Kirpal, A. H. Desai, and G. Subramanium, eds., Supreme but Not Infallible: Essays in Honour of the Supreme Court of India. New Delhi: Oxford University Press, 256-87.

Eisgruber, C. L. and L. G. Sager. 2007. Religious Freedom and the Constitution. Cambridge: Harvard University Press.

Emmerson, D. K. 1978. The Bureaucracy in Political Context: Weakness in Strength. In K. D. Jackson and L. W. Pye, eds., Political Power and Communications in Indonesia. Berkeley: University of California Press, 82-136.

Federspiel, H. M. 1998. Islamic Values, Law, and Expectations in Contemporary Indonesia. Islamic Law and Society 5, 1: 90-117.

Fox, J. 2006. World Separation of Religion and State into the Twenty First Century. Comparative Political Studies 39, 5: 537-69.

Freston, P. 2001. Evangelicals and Politics in Asia, Africa, and Latin America. Cambridge: Cambridge University Press.

Galanter, M. 1989. Law and Society in Modern India. Delhi: Oxford University Press.

Geertz, C. 1960. The Religion of Java. Glencoe, Ill.: The Free Press.

Ginsburg, T. and T. Moustafa. 2008. Rule by Law: The Politics of Courts in Authoritarian Regimes. Cambridge: Cambridge University Press.

Ginting, J. T. 2004. The Position of Hinduism in Karo Society (North Sumatra). In M. Ramstedt, ed., Hinduism in Modern Indonesia: A Minority Religion between Local, National, and Global Interests. London: RoutledgeCurzon, 226-41.

Handberg, R. 1999. Judicialization across Societies: The Spread of Judicial Power and Societal Change. International Journal of Public Administration 22, 8: 1269-92.

Hansen, T. B. 1999. The Saffron Wave: Democracy and Hindu Nationalism in Modern India. New Delhi: Oxford University Press.

Hardacre, H. 1989. Shinto and the State, 1868-1988. Princeton: Princeton University Press.

Hasan, Z. 1994. Minority Identity, State Policy and the Political Process. In Z. Hasan, ed., Forging Identities: Gender, Communities and the State. New Delhi: Kali for Women, 59-73.

Hefner, R. W. 2004. Hindu Reform in an Islamizing Java: Pluralism and Peril. In M. Ramstedt, ed., Hinduism in Modern Indonesia: A Minority Religion between Local, National, and Global Interests. New York: RoutledgeCurzon, 93-108.

Heriyanto Yang, Y. 2005. The History and Legal Position of Confucianism in Postindependence Indonesia. Marburg Journal of Religion 10, 1: 1-8.

Hirschl, R. 2004. Towards Juristocracy: The Origins and Consequences of the New Constitutionalism. Cambridge: Harvard University Press.

Hirschl, R. 2008. The Theocratic Challenge to Constitution Drafting in Post-Conflict States. William and Mary Law Review 49, 4: 1179-211.

Howell, J. D. 1982. Indonesia: Searching for Consensus. In C. Caldarola, ed., Religions and Societies, Asia and the Middle East. New York: Mouton, 497-548. 
Intan, B. F. 2006. "Public Religion" and the Pancasila-Based State of Indonesia: An Ethical and Sociological Analysis. New York: Peter Lang.

Irianto, S. 2005. Race and Gender Discrimination in a Socio-Legal Perspective: The Experience of Chinese Indonesian Women in Indonesia. In L. Lindholt and S. Schaumburg-Müller, eds., Human Rights in Development Yearbook: Human Rights and Local/Living Law. Oslo: Martinus Nijhoff, 235-63.

Jacobsohn, G. J. 2003. The Wheel of Law: India's Secularism in Comparative Constitutional Context. New Delhi: Oxford University Press.

Jones, S. 2013. Indonesian Government Approaches to Radical Islam since 1998. In M. Künkler and A. C. Stepan, eds., Democratization and Islam in Indonesia. New York: Columbia University Press, 109-25.

Kipp, R. S. 1993. Dissociated Identities: Ethnicity, Religion, and Class in an Indonesian Society. Ann Arbor: University of Michigan Press.

Kipp, R. S. and S. Rodgers. 1987. Indonesian Religions in Transition. Tucson: University of Arizona Press.

Kopf, D. 1979. The Brahmo Samaj and the Shaping of the Modern Indian Mind. Princeton: Princeton University Press.

Kusuma, A. B. and R. E. Elson. 2011. A Note on the Sources for the 1945 Constitutional Debates in Indonesia. Bijdragen tot de Taal-, Land-en Volkenkunde 167, 2/3: 196-209.

Lev, D. S. 1972. Islamic Courts in Indonesia: A Study in the Political Bases of Legal Institutions. Berkeley: University of California Press.

Lev, D. S. 2000. Legal Evolution and Political Authority in Indonesia: Selected Essays. The Hague: Kluwer Law International.

Lukito, R. 2003. Law and Politics in Post-Independence Indonesia: A Case Study of Religious and Adat Courts. In A. Salim and A. Azra, eds., Shari 'a and Politics in Modern Indonesia. Singapore: ISEAS, 17-32.

Mahajan, G. 2002. Secularism as Religious Non-Discrimination: The Universal and the Particular in the Indian Context. Indian Review 1, 1: 33-51.

Mahmood, S. T. 1995. Uniform Civil Code: Fictions and Facts. New Delhi: India and Islam Research Council.

Mawardi, A. I. 1998. Socio-Political Background of the Enactment of Kompilasi Hukum Islam Di Indonesia. MA thesis, McGill University, Montreal.

McDaniel, J. 2010. Agama Hindu Dharma Indonesia as a New Religious Movement: Hinduism Recreated in the Image of Islam. Nova Religio: The Journal of Alternative and Emergent Religions 14, 1: 93-111.

Menski, W. 2003. Hindu Law: Beyond Tradition and Modernity. New Delhi: Oxford University Press.

Minor, R. N. 1982. Sarvepalli Radhakrishnan on the Nature of "Hindu" Tolerance. Journal of the American Academy of Religion 50, 2: 275-90.

Minor, R. N. 1999. The Religious, the Spiritual, and the Secular: Auroville and Secular India. Albany: State University of New York Press.

Mitra, S. K. and A. Fischer. 2002. Sacred Laws and the Secular State: An Analytical Narrative of the Controversy over Personal Laws in India. Indian Review 1, 3: 99-130.

Moog, R. S. 1998. Elite-Court Relations in India: An Unsatisfactory Arrangement. Asian Survey 38, 4: 410-23.

Mulder, N. 1978. Mysticism and Everyday Life in Contemporary Java: Cultural Persistence and Change. Singapore: Singapore University Press.

Nehru, J. 1989. Jawaharlal Nehru on Minorities and Secularism. Trivandrum: Institute of Management in Government. 
Nurlaelawati, E. 2010. Modernization, Tradition and Identity: The Kompilasi Hukum Islam and Legal Practice in the Indonesian Religious Courts. Amsterdam: University of Amsterdam Press.

O’Shaughnessy, K. 2009. Gender, State and Social Power in Contemporary Indonesia: Divorce and Marriage Law. London: Routledge.

Pantham, T. 1997. Indian Secularism and Its Critics: Some Reflections. Review of Politics 59, 3: 523-40.

Parsons, N. and M. Mietzner. 2009. Sharia by-Laws in Indonesia. A Legal and Political Analysis. Australian Journal of Asian Law 11, 12: 190-217.

Pausacker, H. 2012. Playboy, the Islamic Defenders' Front and the Law: Enforcing Islamic Norms in Post-Soeharto Indonesia? Australian Journal of Asian Law 13, 1: $1-20$.

Pennington, B. K. 2005. Was Hinduism Invented? Britons, Indians, and Colonial Construction of Religion. Oxford: Oxford University Press.

Ramstedt, M. 2004a. The Hinduization of Local Traditions in South Sulawesi. In M. Ramstedt, ed., Hinduism in Modern Indonesia: A Minority Religion between Local, National, and Global Interests. London: RoutledgeCurzon, 184-225.

Ramstedt, M. 2004b. Introduction: Negotiating Identities-Indonesian 'Hindus' between Local, National, and Global Interests. In M. Ramstedt, ed., Hinduism in Modern Indonesia: A Minority Religion between Local, National, and Global Interests. New York: RoutledgeCurzon, 1-34.

Rana, M. S. 2006. India Votes: Lok Sabha and Vidhan Sabha Elections 2001-2005. New Delhi: Sarup and Sons.

Rao, A. and B. G. Rao. 1974. Six Thousand Days: Jawaharlal Nehru, Prime Minister. New Delhi: Sterling Publishers.

Rao, B. 2004. Religion, Law, and Minorities in India: Problems with Judicial Regulation. In J. T. Richardson, ed., Regulating Religion: Case Studies from around the Globe. New York: Kluwer, 381-413.

Rocher, R. 2010. The Creation of Anglo-Hindu Law. In T. Lubin, D. R. Davis, and J. Krishnan, eds., Hinduism and Law: An Introduction. New York: Cambridge University Press, 78-88.

Sachar, R. 2006. Social, Economic and Educational Status of the Muslim Community of India. New Delhi: Prime Minister's High Level Committee.

Salim, A. 2008. Challenging the Secular State: The Islamization of Law in Modern Indonesia. Honolulu: University of Hawai'i Press.

Sathe, S. P. 2003. Judicial Activism in India. 2d ed. Delhi: Oxford University Press.

Scheingold, S. A. 2004. The Politics of Rights: Lawyers, Public Policy, and Political Change. 2d ed. Ann Arbor: University of Michigan Press.

Schiller, A. 1996. An "Old” Religion in "New Order" Indonesia: Notes on Ethnicity and Religious Affiliation. Sociology of Religion 57, 4: 409-17.

Schrauwers, A. 2000. Colonial 'Reformation' in the Highlands of Central Sulawesi, Indonesia, 1892-1995. Toronto: University of Toronto Press.

Sen, R. 2010. Articles of Faith: Religion, Secularism, and the Indian Supreme Court. New Delhi: Oxford University Press.

Sezgin, Y. 2013. Human Rights under State-Enforced Religious Family Laws in Israel, Egypt and India. Cambridge: Cambridge University Press.

Smith, D. E. 1963. India as a Secular State. Princeton: Princeton University Press.

Smith, J. Z. 1998. Religion, Religions, Religious. In M. C. Taylor, ed., Critical Terms for Religious Studies. Chicago: University of Chicago Press, 269-84.

Stump, R. W. 2000. Boundaries of Faith: Geographical Perspectives on Religious Fundamentalism. Lanham, Md.: Rowman and Littlefield. 
Surbakti, R. A. 1991. Interrelation between Religious and Political Power under New Order Indonesia. PhD diss., Northern Illinois University, DeKalb.

Sweet, A. S. 2003. Constitutional Courts and Parliamentary Democracy. In M. Thatcher and A. Stone Sweet, eds., The Politics of Delegation. London: Frank Cass, 69-89.

Tallberg, J. 2003. Delegation to Supranational Institutions: Why, How, and with What Consequences? In M. Thatcher and A. Stone Sweet, eds., The Politics of Delegation. London: Frank Cass, 23-46.

Tate, C. N. 1993. Courts and Crisis Regimes: A Theory Sketch with Asian Case Studies. Political Research Quarterly 46, 2: 311-38.

Tate, C. N. 1995. Why the Expansion of Judicial Power. In C. N. Tate and T. Vallinder, eds., The Global Expansion of Judicial Power. New York: New York University Press, 27-37.

Thatcher, M. and A. S. Sweet. 2003. Theory and Practice of Delegation to NonMajoritarian Institutions. In M. Thatcher and A. Stone Sweet, eds., The Politics of Delegation. London: Frank Cass, 1-22.

Williams, R. V. 2006. Postcolonial Politics and Personal Laws: Colonial Legal Legacies and the Indian State. New Delhi and Oxford: Oxford University Press.

Zavos, J. 2002. The Emergence of Hindu Nationalism in India. New Delhi: Oxford University Press.

Abstract: This article compares the strategies through which Hindu-majority India and Muslim-majority Indonesia have regulated religion and addressed questions of what constitutes "the religious" in the post-independence period. We show that the dominant approach pursued by the Indian state has been one of judicialization - the delegation of religious questions to the high courts - while in Indonesia it has predominantly been one of bureaucratization - the regulation of religious issues by the Ministry of Religious Affairs. Contrary to the expectation that judicialization devitalizes normative conflicts while bureaucratization, more frequently associated with authoritarian politics, "locks" these conflicts "in," we show that these expectations have not materialized, and at times, the effects have been reverse. Engaging the literatures on judicialization and on bureaucratization, we argue that what determines the consequences of the policy toward religion is less the choice of the implementing institution (i.e., the judiciary or bureaucracy) than the mode of delegation (vertical versus horizontal) which shapes the relationship between the policy-maker and the institution implementing it. Bureaucrats, judges, and elected politicians in multicultural societies around the world encounter questions of religious nature very similar to those that authorities in India and Indonesia have faced. How they address the challenge of religious heterogeneity has a profound impact on prospects of nation-building and democratization. It is therefore imperative that the consequences of the policy toward religion, and even more so the consequences of political delegation, be studied more systematically. 